\title{
In vitro inhibition of monkeypox virus production and spread by Interferon- $\beta$
}

Sara C Johnston ${ }^{1 *}$, Kenny L Lin ${ }^{1}$, John H Connor ${ }^{3}$, Gordon Ruthel ${ }^{2}$, Arthur Goff ${ }^{1}$ and Lisa E Hensley ${ }^{1}$

\begin{abstract}
Background: The Orthopoxvirus genus contains numerous virus species that are capable of causing disease in humans, including variola virus (the etiological agent of smallpox), monkeypox virus, cowpox virus, and vaccinia virus (the prototypical member of the genus). Monkeypox is a zoonotic disease that is endemic in the Democratic Republic of the Congo and is characterized by systemic lesion development and prominent lymphadenopathy. Like variola virus, monkeypox virus is a high priority pathogen for therapeutic development due to its potential to cause serious disease with significant health impacts after zoonotic, accidental, or deliberate introduction into a naïve population.

Results: The purpose of this study was to investigate the prophylactic and therapeutic potential of interferon- $\beta$ (IFN- $\beta$ ) for use against monkeypox virus. We found that treatment with human IFN- $\beta$ results in a significant decrease in monkeypox virus production and spread in vitro. IFN- $\beta$ substantially inhibited monkeypox virus when introduced 6-8 h post infection, revealing its potential for use as a therapeutic. IFN- $\beta$ induced the expression of the antiviral protein MxA in infected cells, and constitutive expression of MxA was shown to inhibit monkeypox virus infection.
\end{abstract}

Conclusions: Our results demonstrate the successful inhibition of monkeypox virus using human IFN- $\beta$ and suggest that IFN- $\beta$ could potentially serve as a novel safe therapeutic for human monkeypox disease.

Keywords: Orthopoxvirus, Monkeypox virus, Type I interferon, IFN- $\beta$, MxA

\section{Background}

The Orthopoxvirus genus of the family Poxviridae contains a number of pathogens known to infect humans, including variola virus (VARV, the causative agent of smallpox), cowpox virus, camelpox virus, vaccinia virus, and monkeypox virus (MPXV). Human infection with members of this genus results in varying degrees of morbidity and mortality. Virions are enveloped and brickshaped, with a dumbbell shaped core containing the genetic material [1]. Orthopoxviruses contain a single, linear piece of double-stranded DNA with highly conserved central regions and more variable terminal ends [1]. The proteins expressed from the terminal ends are predominantly involved in immunomodulation and/or host range determination [2-4].

\footnotetext{
* Correspondence: sara.johnston@amedd.army.mil

'Virology Division, United States Army Medical Research Institute of

Infectious Diseases, 1425 Porter St. Fort Detrick, Frederick, MD 21702, USA

Full list of author information is available at the end of the article
}

VARV, the etiological agent of smallpox, causes an acute, systemic lesional disease with a mortality rate of approximately 30\% [5,6]. Eradicated in 1977, smallpox remains a constant threat due to its potential use as a biological weapon for mass dissemination to a largely unprotected worldwide population. Unfortunately, VARV is not the only member of the Orthopoxvirus genus that causes severe disease in humans and has the potential for development as a biological weapon. The global eradication of smallpox and the subsequent cessation of smallpox vaccination in 1980 allowed for the emergence of another lethal zoonotic disease, monkeypox.

Similar to smallpox, monkeypox is a systemic lesional disease with a prodrome period of flu-like symptoms (fever, malaise, chills, headache) followed by the development of a progressive maculopapular rash which expands in a centrifugal pattern and progresses from papules to vesicles to pustules and finally to crusts [7-11]. MPXV is a zoonotic virus endemic in the Democratic Republic of the Congo (DRC) where it regularly emerges from

\section{Ciomed Central}


reservoir species, including squirrels and other rodents [12-14], to cause serious disease outbreaks in humans. The best estimate of mortality rate is approximately $10 \%$; however, this is likely an underrepresentation due to sporadic reporting since 1986 and a lack of information concerning the complete geographic range of human monkeypox disease [9,15-18].

There are 2 distinct clades of MPXV, West African and Central African. MPXV strains belonging to the West African clade are far less virulent than Central African strains in both humans and non-human primates, with diminished morbidity and human-to-human transmissibility $[19,20]$. The MPXV outbreak that occurred in the Midwestern United States in 2003 was caused by a West African strain of MPXV and thus resulted in less severe disease than what is typically seen in outbreaks in Central Africa [21]. This outbreak did, however, demonstrate the ability of MPXV to reach beyond the African continent and cause disease in MPXV-naïve populations. Although outbreaks of Central African monkeypox have not been seen outside of Africa, predictions based on an ongoing active disease surveillance study in the DRC suggest that spread to a MPXV-naïve population could have significant public health impacts. This study was conducted in nine health zones in the DRC and revealed a dramatic increase in monkeypox cases, with 760 laboratory confirmed cases identified from 2005 to 2007 [18]. Although previous vaccination against smallpox was found to still confer significant protection, only approximately $25 \%$ of the population in the sampled health zones had evidence of past vaccination [18]. Data suggesting that the incidence of human-tohuman transmission of MPXV is on the rise in this region is also concerning $[18,22]$ and could suggest that fading herd immunity coincident with a rise in the number of unvaccinated persons is allowing for more efficient spread. Additionally, it is possible that genetic variants are emerging that are more highly adapted to humans. Taken together with a long incubation period, which allows for a significant period of time during which a person is potentially contagious but asymptomatic, and its potential use as a biological weapon, it is evident that the development of therapeutic methods to treat active MPXV infections is critical.

In this paper, we investigate the potential use of interferon (IFN) $\beta$ as an anti-MPXV therapeutic. IFN- $\beta$ is already US Food and Drug Administration (FDA) approved for the treatment of multiple sclerosis in four forms: Betaseron, Rebif, Avonex, and Extavia. All of these products have well-defined safety records for human use (FDA).

IFN- $\beta$ is a type I IFN that plays a key role in the innate immune response by promoting the production of IFN-stimulated genes that inhibit protein synthesis, induce apoptosis, and activate macrophages and natural killer cells [23-25]. Additionally, type I IFNs enhances the adaptive immune response by upregulating major histocompatibility complex-I/II expression on the surface of antigen-presenting cells [23-25].

IFNs have been generally overlooked as anti-Orthopoxvirus agents due to the large number of immunomodulatory proteins expressed by viruses belonging to this genus. To date, 13 Orthopoxvirus proteins have been shown to have anti-IFN activity: A46, A52, K7, N1, B14, K1, M2, COP-B19, B8, H1, E3, K3, and C7 [26]. Recently, a 14th protein was identified, VARV-G1R, which binds to NF- $\kappa$ B and inhibits NF- $\kappa \mathrm{B}$ regulated gene expression [27]. Some of these proteins have also been shown to play key roles in host range determination and virulence during vaccinia virus infection. Unfortunately, most of these proteins have not been fully characterized, and the activity of orthologs expressed by MPXV and VARV has not been extensively investigated at this time. One of the best characterized of these proteins is E3. E3 has been studied in vaccinia virus and is known to block the activation of PKR [28-30]. Although VARV contains a full length and fully functional E3L, MPXV lacks the N-terminal domain responsible for binding Z-DNA and PKR [11,30,31]. Removal of this domain results in a decreased virulence in murine models of vaccinia infection [32]. K3 is a homolog of eIF-2 $\alpha$ that sequesters PKR thereby preventing phosphorylation of native eIF- $2 \alpha$ by PKR [33-35]. It is a host range gene that is expressed by both VARV and vaccinia virus but not by MPXV $[11,36]$. C7 and K1 have also been shown to affect the cell tropism of vaccinia virus [37-40]. Although their exact functions are less well understood, it is believed that they employ a novel mechanism to antagonize IFN $[37,41]$. While the role of VARV-G1 in host range restriction has not been explicitly demonstrated, G1 orthologs are present in some of the most highly pathogenic Orthopoxviruses, including VARV and MPXV, but not in vaccinia virus, suggesting that this protein may be a key virulence factor [27].

The detailed comparative study of COP-B19 orthologs from MPXV and VARV represents the first cross-species functional analysis of any of the anti-IFN immunomodulators [42]. In this study, COP-B19 (aka B18 or IFN $\alpha / \beta R$ ) from vaccinia virus was found to react very strongly with human and murine IFN- $\alpha$ and IFN- $\beta$. In contrast, the VARV ortholog, B17, bound to murine IFN- $\beta$ very poorly but bound to human IFN- $\beta$ better than vaccinia B18. Although this study didn't give as detailed of a description of the binding properties of MPXV B16, it did suggest that immunomodulatory proteins such as COP-B19 may play significant roles in host range restriction. Additionally, it showed that the analysis of Orthopoxvirus immunomodulatory proteins cannot be limited to vaccinia virus but must be carried out for all Orthopoxviruses as orthologs may function differently and/or be affected to varying 
degrees by the host immune response. The genetic and functional variability of the immunomodulatory proteins necessitate that prophylactic or therapeutic agents that are intended to overcome the action of these proteins be tested for efficacy with all Orthopoxviruses as the susceptibility of these viruses may vary significantly.

Although IFN- $\beta$ has been shown to substantially diminish vaccinia virus pathogenesis in vivo [43,44], the susceptibility of MPXV to IFN- $\beta$ is uncertain. In this study, we found that MPXV production and release were significantly reduced in the presence of IFN $-\beta$. Additionally, IFN- $\beta$ was able to inhibit MPXV when introduced 6-8 $\mathrm{h}$ after infection, revealing its potential for use as a therapeutic against established infections. IFN- $\beta$ treatment was able to induce the expression of the antiviral protein MxA during MPXV infection, and constitutive expression of MxA was able to inhibit virus production. Collectively, the data show that IFN- $\beta$ is a strong novel candidate for further investigation as a prophylactic and therapeutic against MPXV.

\section{Results}

\section{MPXV was inhibited by IFN- $\beta$}

Although IFN- $\beta$ has been used alone and in combination with other cytokines in studies involving vaccinia virus, the response of MPXV to IFN- $\beta$ treatment had not been previously investigated. HeLa cells that were pre-treated for 24 hours (h) before infection with increasing concentrations of IFN- $\beta$ (0-5000 units $[\mathrm{U}] / \mathrm{ml})$ were infected with MPXV-Zaire at a high multiplicity of infection (MOI). The cells were harvested $24 \mathrm{~h}$ post infection (p.i.) and virus present titered by plaque assay. Titration results indicated that MPXV was susceptible to inhibition by IFN- $\beta$ with concentrations as low as $600 \mathrm{U} / \mathrm{ml}$, and an optimal approximately $91 \%$ reduction was seen with $2000 \mathrm{U} / \mathrm{ml}$ of IFN- $\beta$ (Figure 1a). Examination of IFN- $\beta$ treated HeLa cells using the CellTiter-Glo Luminescent Cell Viability Assay (Promega, Madison, WI) confirmed that there was no observable toxicity from IFN treatments (Figure 1a). Based on the dose response curves and lack of observable cellular toxicity, a $2000 \mathrm{U} / \mathrm{ml} 24 \mathrm{~h}$ pre-treatment was selected for further experimentation.

To specifically investigate infectious virus production and release in the presence of IFN- $\beta$, a high MOI growth curve using MPXV-Zaire was performed. Although virus replication still occurred in cells treated with IFN- $\beta$, we observed an approximately $1 \log$ reduction in cell-associated and released virus 24-48 h p.i. in the presence of IFN- $\beta$ compared to untreated controls (Figure 1b).

The recombinant virus MPXV-GFP-tdTR, which expresses green fluorescent protein (GFP) from an early MPXV promoter and Tomato Red (TR) from a late MPXV promoter, allows visualization of early and late gene expression. Fluorescence microscopy of recombinant plaques demonstrated uniform distribution and complete colocalization of GFP and TR signal (Figure 2a). Cells infected in the presence of cytosine- $\beta$-D-arabinofuranoside (Ara-C), which allows early gene expression but inhibits DNA replication and subsequently late gene expression, showed a complete knockdown of only TR expression (Figure 2b), verifying the expression profile of GFP and TR. A time course experiment using flow cytometry also demonstrated GFP expression as early as $2 \mathrm{~h}$ p.i. and TR expression between 9 and $12 \mathrm{~h}$ p.i. (data not shown). Growth curves using high MOI inoculums were performed with both wild type and MPXV-GFP-tdTR and showed no significant difference in the amount of cell-or mediumassociated virus (Figure 2c), indicating that incorporation of the two fluorescent genes had no impact on virus growth kinetics.

Fluorescence microscopy and a relative fluorescence assay of IFN- $\beta$ pre-treated, MPXV-GFP-tdTR infected cells revealed a significant reduction of GFP expression in the presence of IFN- $\beta$ compared to untreated controls (Figure 3). TR expression was also reduced compared to untreated controls (Figure 3); however, the amount of GFP and TR expression in treated cells was similar, suggesting a role for IFN $-\beta$ in blocking early gene expression.

Pathogenesis in a host system requires that MPXV spread efficiently from cell to cell. To look at cell-to-cell spread in vitro, we performed a low MOI growth curve using MPXV-Zaire. In the presence of IFN- $\beta$, the amount of cell-associated virus was reduced by greater than a log at $48-72$ h p.i. (Figure $4 a$ ); however, by 120 h p.i., infectious virus levels were comparable to untreated controls. A similar trend was observed when medium-associated virus was titered (Figure 4b). Therefore, MPXV spread is attenuated in vitro in the presence of IFN- $\beta$.

\section{Expression of IFN-induced MxA inhibits MPXV infection}

MxA is a large GTPase induced by IFN that has been shown to have antiviral activity [45-51]. MxA expression in cells infected with MPXV in the presence of IFN- $\beta$ was assessed. Immunostains for MxA and the viral protein A33 demonstrated a diffuse cytoplasmic pattern of MxA in uninfected, IFN $-\beta$ pre-treated cells that was consistent with previous reports [52] while MxA expression in MPXV infected cells was only observed when cells were pre-treated with IFN- $\beta$ (Figure 5). In infected cells treated with IFN $-\beta$, MxA was localized into distinct punctate regions, and some co-localization with A33 in the cytoplasm and at the site of wrapping was observed (Figure 5).

To determine whether MPXV late protein production was necessary for the re-distribution of MxA, infected (and IFN- $\beta$ treated) cells were incubated with Ara-C which inhibits viral replication and subsequent late gene expression. Similar punctate regions of MxA staining were observed in both the presence and absence of Ara-C in 


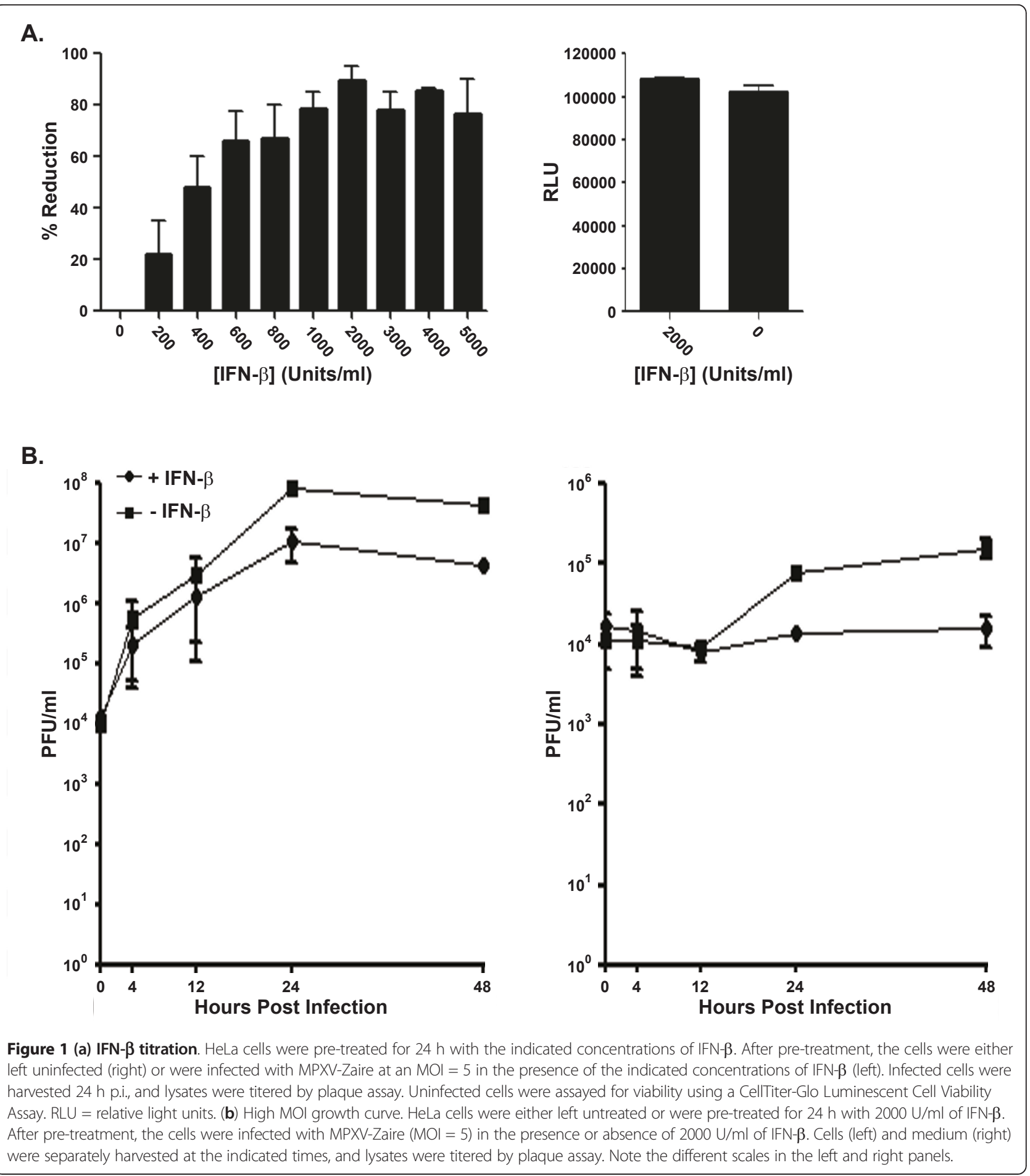

infected cells (Figure 6), demonstrating that neither replication nor late protein production is necessary for the relocalization of MxA during MPXV infection.

VA-9, a cell line that constitutively expresses MxA, [53] and the parental control cell line VN36 [53] were infected with MPXV-Zaire at a high MOI to look at the antiviral activity of MxA against MPXV. We observed an approximately 91\% reduction in the amount of infectious virus present in VA-9 cells compared to VN36 control cells (Figure 7a). To confirm these results, we performed fluorescence microscopy on VA-9 and VN36 cells infected with MPXV-GFP-tdTR at a high MOI, and the relative fluorescence was measured. Again, we observed a statistically significant inhibition of infection 
A.

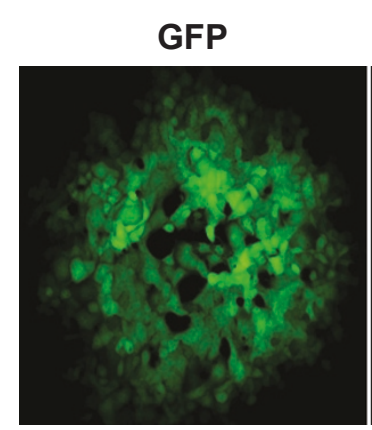

B.
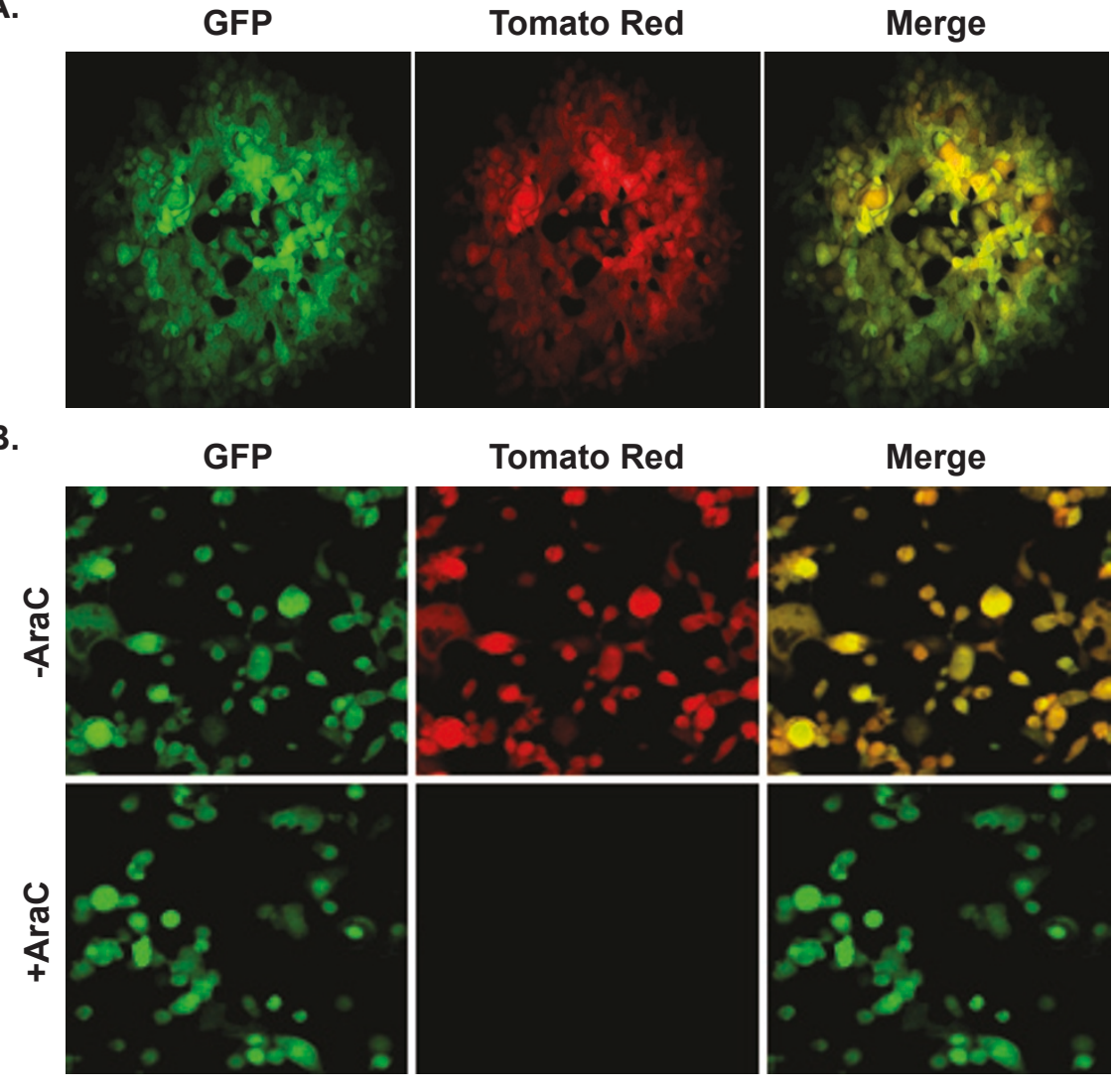

C.
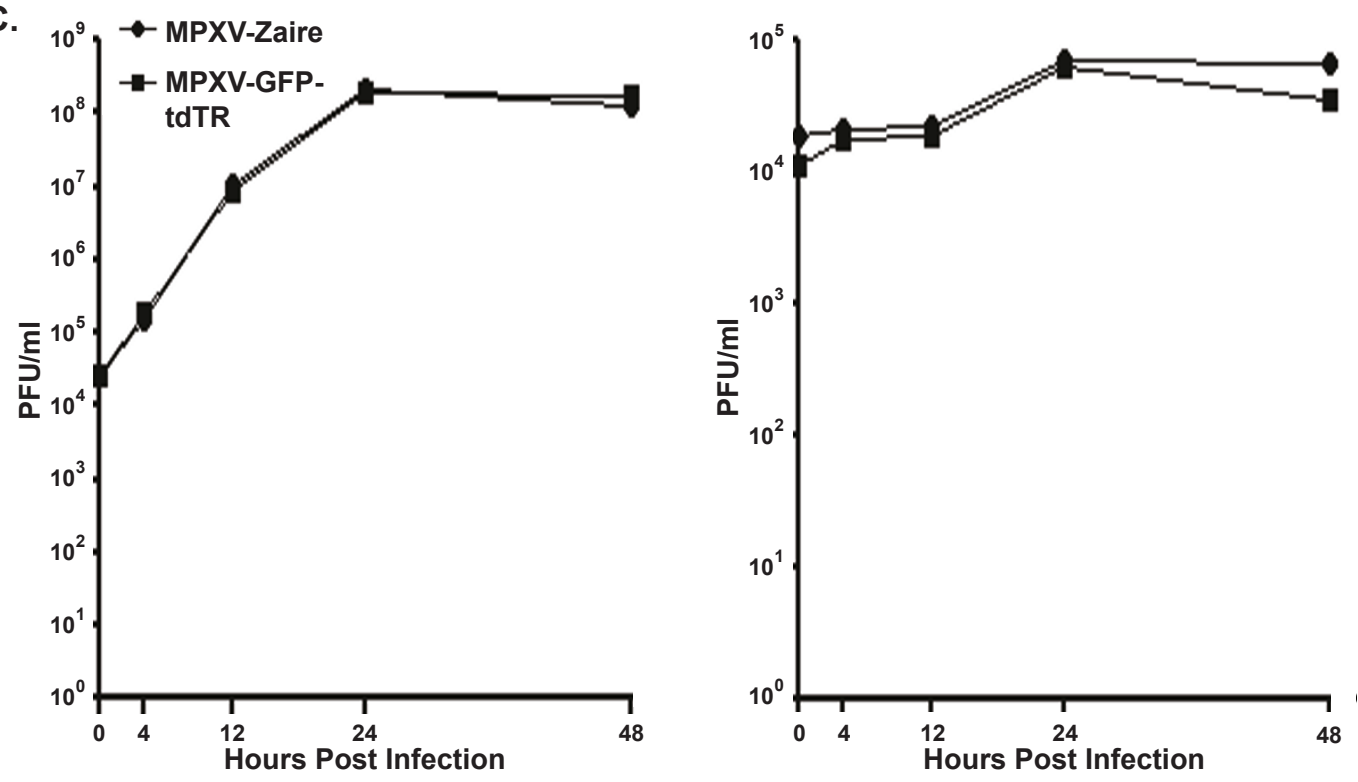

Figure 2 Characterization of MPXV-GFP-tdTR. (a) Vero-E6 cells infected with MPXV-GFP-tdTR were imaged 48 h p.i. by fluorescence microscopy. A single representative plaque is shown. Green is GFP, red is Tomato Red, and yellow represents the overlap of green and red fluorescence. (b) Vero-E6 cells infected with MPXV-GFP-tdTR $(\mathrm{MOI}=5)$ in the presence or absence of Ara-C were imaged after $48 \mathrm{~h}$ by fluorescence microscopy. Green is GFP, red is Tomato Red, and yellow represents the overlap of green and red fluorescence. (c) High MOI growth curve. HeLa cells were infected with MPXV-GFP-tdTR at an MOI = 5. Cells (left) and medium (right) were separately harvested at the indicated times, and lysates were titered by plaque assay. Note the different scales for cell and media graphs. 


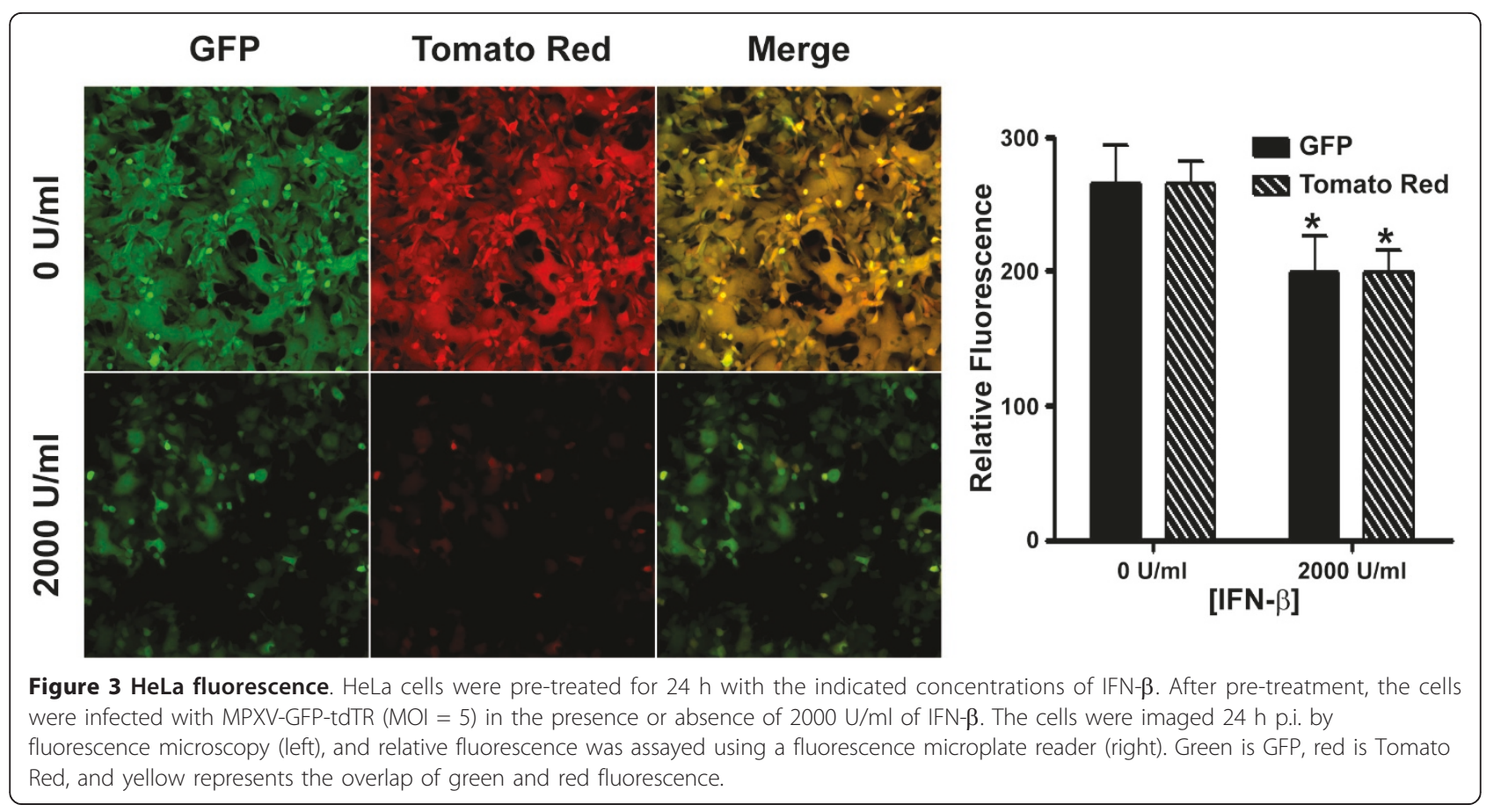

as both early and late gene expression appeared to be equally reduced in the presence of MxA (Figure 7b), demonstrating a role for $\mathrm{MxA}$ in the inhibition of MPXV by IFN- $\beta$.

It was previously shown that a mutant form of MxA containing a Glu-to-Arg substitution at amino acid 645 [MxA(E645R)] lost its ability to inhibit infection by vesicular stomatitis virus and African swine fever virus (ASFV) but retained its inhibitory effect over influenza virus and thogoto virus $[49,53,54]$. To test the susceptibility of MPXV to this mutant MxA, VA(R645) cells were infected with MPXV-Zaire at an MOI $=5$. Although we still observed an approximately $91 \%$ inhibition in VA9 cells, we observed no reduction of infectious virus production in VA(R645) cells (Figure 8), suggesting that MPXV is resistant to inhibition by MxA(E645R).

\section{Post infection treatment with IFN- $\beta$ was able to inhibit MPXV-Zaire}

To test the therapeutic limit of IFN- $\beta$, HeLa cells infected at a high MOI with MPXV-Zaire were treated with IFN- $\beta$ at $0,2,4,6,8$, or $12 \mathrm{~h}$ p.i.. An approximately $91 \%$ reduction in infectious virus was observed when IFN- $\beta$ was added 6-8 h p.i. (Figure 9a), suggesting that IFN- $\beta$ can significantly inhibit MPXV when added during an active infection.

\section{MPXV is highly susceptible to IFN- $\beta$ inhibition in human primary cells}

Human primary cells more closely resemble an in vivo situation than immortalized cell lines (such as HeLa cells) and were, therefore, used to examine the susceptibility of MPXV under more physiologically relevant conditions. Normal human dermal fibroblasts that were pre-treated for $24 \mathrm{~h}$ before infection with increasing concentrations of IFN- $\beta(0-5000 \mathrm{U} / \mathrm{ml})$ were infected with MPXV-Zaire at a high MOI. The cells were harvested $24 \mathrm{~h}$ p.i. and virus present titered by plaque assay. An approximately $95 \%$ reduction in infectious virus was observed with the lowest concentration of IFN- $\beta$ ( $25 \mathrm{U} / \mathrm{ml})$, with maximum inhibition of approximately $99 \%$ observed at concentrations greater than or equal to $1000 \mathrm{U} / \mathrm{ml}$ (Figure 9b). In HeLa cells, this level of inhibition was not even seen with the highest concentration of IFN- $\beta$ (5000 U/ml) (Figure 1a), demonstrating that MPXV susceptibility to IFN- $\beta$ is enhanced when primary cells are used.

\section{Discussion}

In this report, we described the potential use of IFN- $\beta$ as a novel anti-MPXV therapeutic. Previous reports have shown that exogenously introduced type I IFN protects non-human primates from lesion development after vaccinia virus challenge [44], and IFN- $\beta$ expressed by a recombinant vaccinia virus is $100 \%$ effective at preventing mortality in mice $[43,44]$. Here, we showed that IFN- $\beta$ is capable of significantly reducing MPXV infection. Fluorescence microscopy suggested that IFN- $\beta$ treatment resulted in an antiviral state that is capable of interfering with infection, and high and low MOI growth curves demonstrated that MPXV production, release, and spread were reduced by IFN- $\beta$. 


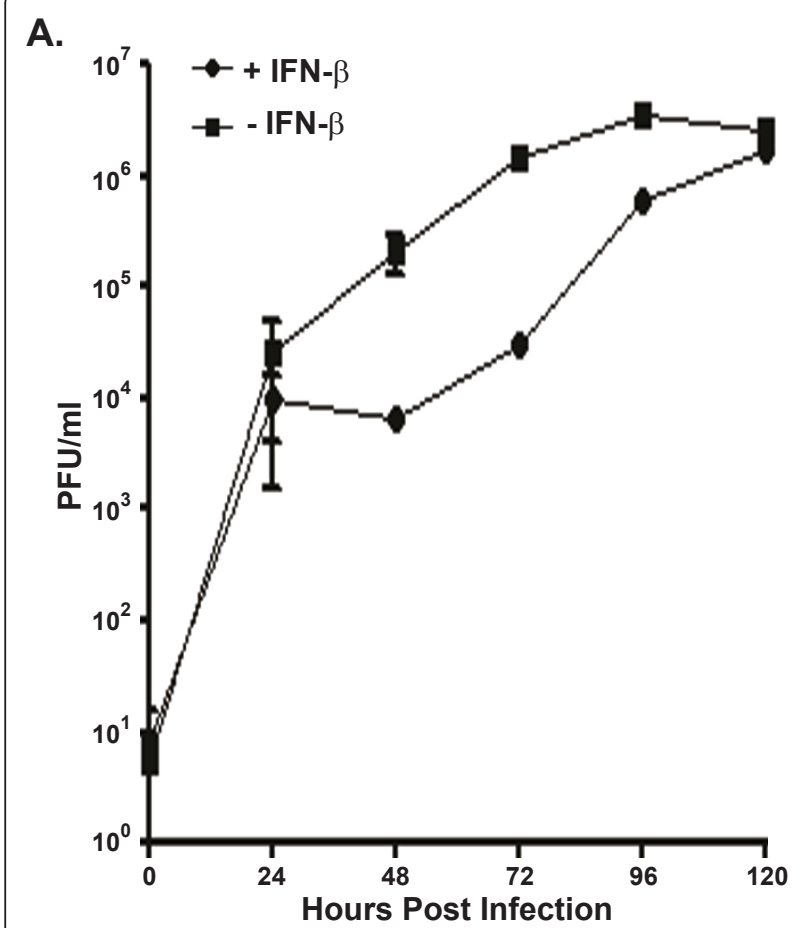

B.

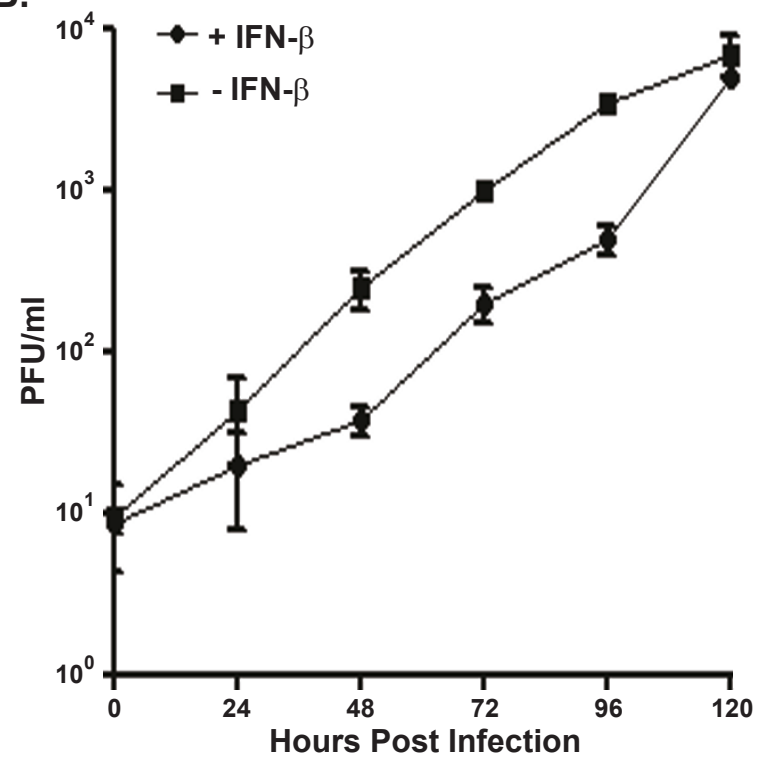

Figure 4 Low MOI growth curve. HeLa cells were either left untreated or were pre-treated for $24 \mathrm{~h}$ with $2000 \mathrm{U} / \mathrm{ml}$ of IFN- $\beta$. After pretreatment, the cells were infected with MPXV- Zaire at an MOI $=0.01$ in the presence or absence of $2000 \mathrm{U} / \mathrm{ml}$ of IFN- $\beta$. Cells (a) and medium (b) were separately harvested at the indicated times, and lysates were titered by plaque assay. Note the different scales in (a) and (b).

Based on immunological studies of IFN- $\beta$, it is likely that the effect of IFN- $\beta$ on MPXV is multifaceted and dependent on numerous effector molecules belonging to the Type I IFN signaling cascade. In this report, we showed that one such molecule, MxA, has a significant inhibitory effect on MPXV. MxA has antiviral activity against numerous RNA viruses including influenza viruses, bunyaviruses, thogoto virus, measles virus, human parainfluenza virus 3 , vesicular stomatitis virus, Semliki Forest virus, and hepatitis B virus [45-51], as well as the DNA-containing ASFV [49]. Like MPXV, ASFV is a large, double stranded DNA virus that replicates entirely in the cytoplasm of the infected cell. Similar to ASFV, we showed that MPXV is inhibited by MxA but is resistant to inhibition by the mutant MxA(E645R). Additionally, MxA is relocalized following infection with both MPXV and ASFV, and this relocalization is independent of late protein production. In ASFV infected cells, MxA appears to be recruited to the site of virus assembly. Similarly, the majority of MxA in MPXV infected cells appeared to be located at the site of virus envelopment. MxA relocalization was still observed in the presence of Ara-C during MPXV infection but not ASFV infection, suggesting that MxA relocalization is independent of MPXV replication. We did not investigate the specific mode of action of MxA against MPXV as this was beyond the scope of this study which focused predominantly on the effectiveness of IFN- $\beta$ against MPXV as justification for its further development as a therapeutic against highly pathogenic Orthopoxviruses. However, the data suggest that the method by which MxA inhibits MPXV might be similar to its inhibition of ASFV.

There is evidence in the literature that in vitro tests likely underestimate the inhibitory effect of IFNs on Orthopoxviruses in vivo, where additional immune defenses could act in concert with IFN signaling. Type I IFN has been shown to protect mice and non-human primates from morbidity and mortality after challenge with the closely related vaccinia virus $[43,44]$. Additionally, studies have shown that as little as a 1-2 log reduction in MPXV significantly reduces morbidity and mortality in non-human primates [55]. We, therefore, hypothesize that the effect of IFN- $\beta$ on MPXV infectivity would be even greater in vivo, resulting in significant reductions in morbidity and mortality. In support of this prediction, we observed a much greater reduction in infectious MPXV by IFN- $\beta$ when a primary cell line (normal human dermal fibroblast cells), which more closely mimics the in vivo state, was used. Collectively, the data presented in this report support the further development of IFN- $\beta$ as a novel anti-MPXV countermeasure.

\section{Conclusions}

Thirty years after the cessation of the smallpox vaccination campaign, dramatic increases in MPXV prevalence in the DRC [18] have raised concerns that the increasing size of the unvaccinated population is allowing for higher rates of zoonosis, and suggest a much greater risk of transmission 


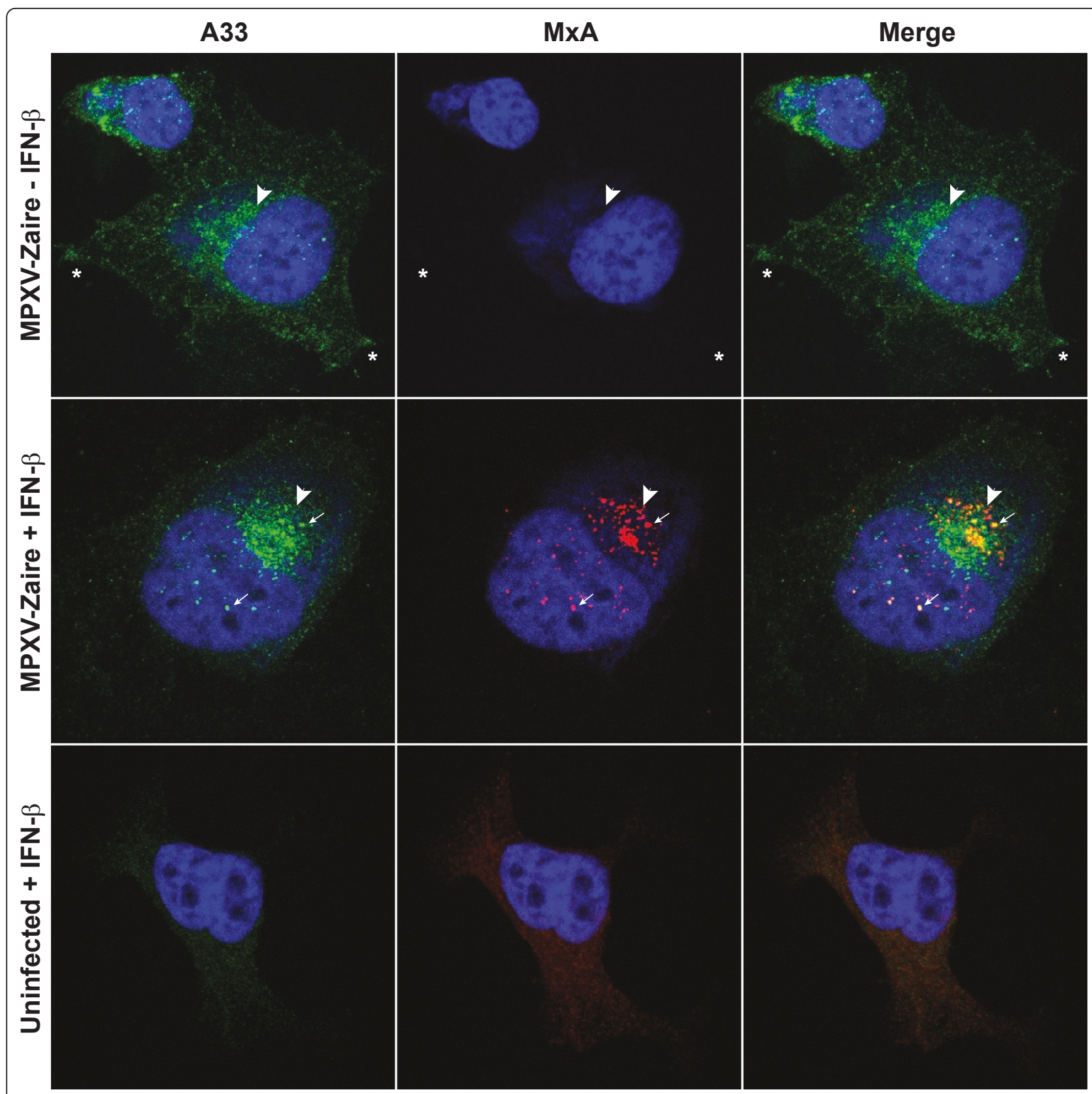

Figure $\mathbf{5}$ Confocal microscopy of $\mathbf{M x A}$ in infected cells. HeLa cells on coverslips were either left untreated or were pre-treated for $24 \mathrm{~h}$ with $2000 \mathrm{U} / \mathrm{ml}$ of IFN- $\beta$. After pre-treatment, the cells were infected with MPXV-Zaire at an $\mathrm{MOI}=1$ in the presence or absence of $2000 \mathrm{U} / \mathrm{ml}$ of IFN- $\beta$. Coverslips were harvested, fixed, permeabilized, and immunostained for MxA and A33 24 h p.i.. The coverslips were stained with Hoechst dye, mounted onto slides, and imaged by confocal microscopy. Green is A33, red is MxA, blue is Hoechst dye, and yellow represents the overlap of green and red fluorescence. Arrowheads point to the site of envelopment, arrows point to distinct areas of signal overlap, and asterisks denote the cell vertices.

to other susceptible populations worldwide. In 2003, a chain of seven generations of uninterrupted human-tohuman spread revealed that an unprotected population could potentially sustain a MPXV outbreak [11]. Additionally, mutations that result in a virus that is better adapted to humans could strengthen transmissibility and pathogenesis. Based on information gained during active disease surveillance studies in the DRC [18], there is growing concern that the introduction of a virulent strain of MPXV into an area where little or no anti-Orthopoxvirus immunity exists, such as in the United States, could result in an epidemic with significant public health implications. Therefore, the development of countermeasures against MPXV and closely related VARV is of great importance. 


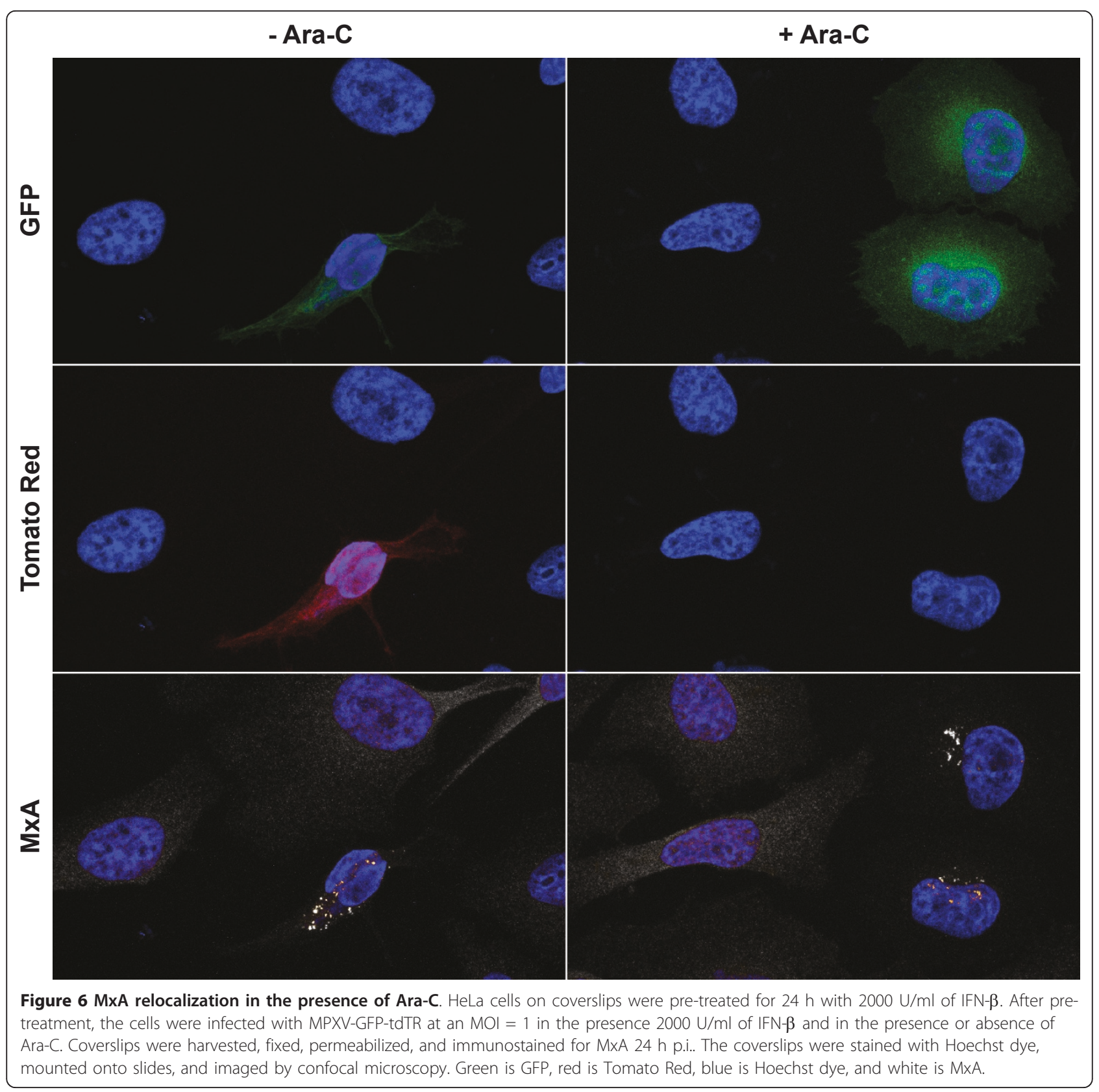

To this day, vaccination still remains the most effective anti-Orthopoxvirus prophylactic. However, these vaccines are the most reactogenic of all FDA-approved vaccines, prompting the cessation of their generalized use in 1980 due to the unnecessary risk of complications in the absence of an active smallpox epidemic [56,57]. Under current guidelines these vaccines will be contraindicated for 1 in 5 individuals $[5,58,59]$, including individuals who have heart disease, skin disorders, and/or have a weakened immune system [57]. The risks associated with live vaccines have prompted the investigation into safer alternatives, including attenuated and subunit vaccines $[56,57]$.
The development of therapeutics that can treat established infections caused by outbreak or accidental exposure (such as by laboratory accident) or to minimize/treat adverse events caused by vaccination is ongoing, and currently no therapeutics have been licensed for widespread use against Orthopoxviruses. Additionally, the development of at least two therapeutics with distinct mechanisms of action is required before the destruction of the remaining stores of VARV can even be considered. Cidofovir and its derivatives [60-63] and Gleevec [64,65] have been investigated for this purpose. Presently the most promising candidate is ST-246 which specifically targets the virus by 
A.

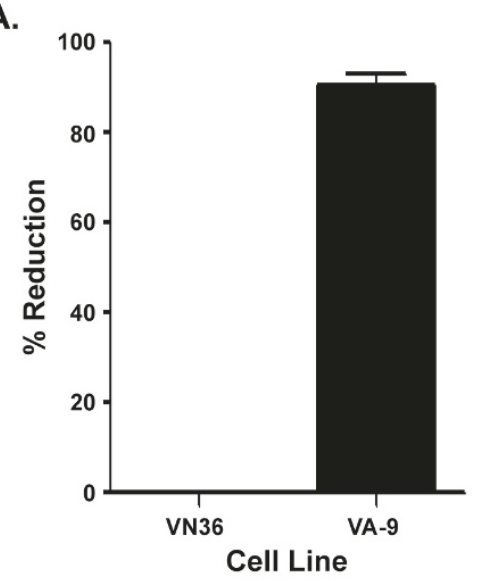

B.
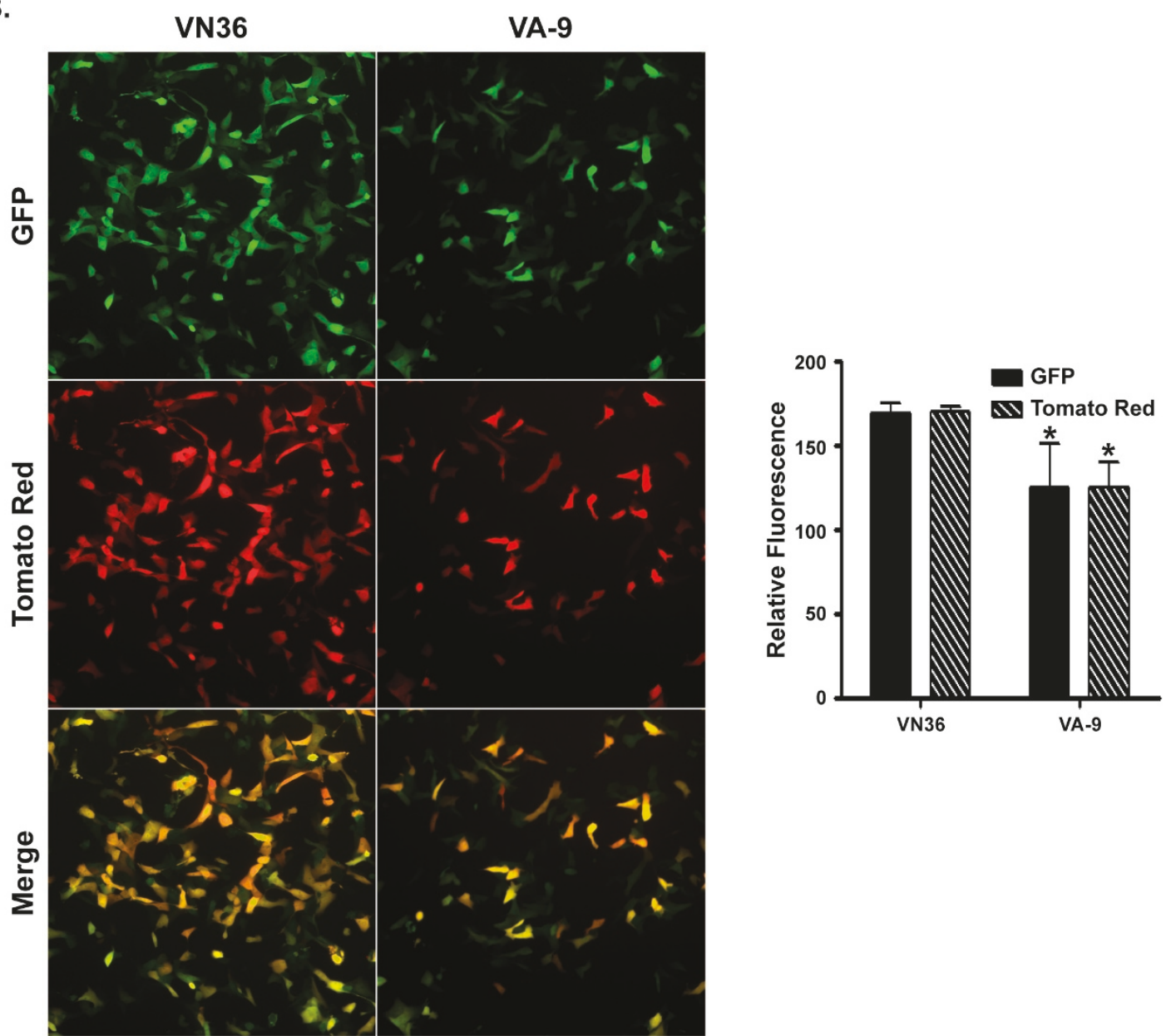

Figure 7 Infection of cells constitutively expressing MxA. (a) VA-9 and VN36 cells were infected with MPXV-Zaire at an MOI = 5. The cells were harvested and lysed $24 \mathrm{~h}$ p.i., and the amount of virus present in the lysates was titered by plaque assay. (b) VA-9 and VN36 cells were infected with MPXV-GFP-tdTR at an MOI $=5$. The cells were imaged $24 \mathrm{~h}$ p.i. by fluorescence microscopy (left), and relative fluorescence was measured using a fluorescence microplate reader (right). Green is GFP, red is Tomato Red, and yellow represents the overlap of green and red fluorescence. 


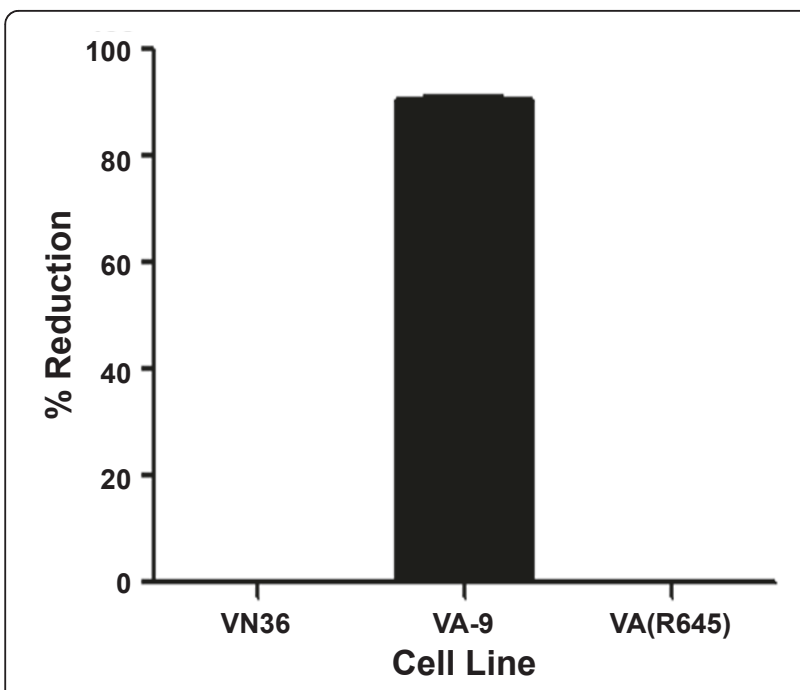

Figure 8 MPXV resistance to $\operatorname{MxA(E645R).~VA-9,~VA(R645),~and~}$ VN36 cells were infected with MPXV-Zaire at an MOI $=5$. The cells were harvested and lysed $24 \mathrm{~h}$ p.i., and the amount of virus present in the lysates was titered by plaque assay.

inhibiting the viral protein F13 [55,66]. In this report, we investigated the in vitro effectiveness of a novel candidate therapeutic, IFN- $\beta$, against MPXV. IFN- $\beta$ is an attractive therapy because it is already in use to treat multiple sclerosis, it is readily available and has a well-defined safety profile, and it could be quickly implemented and used offlabel. Due to the limited amount of information available concerning the function of the various anti-IFN proteins expressed by Orthopoxviruses (reviewed in the introduction), particularly the highly pathogenic MPXV and VARV, data obtained from investigating the therapeutic potential of IFN- $\beta$ against these viruses might also prove to be pivotal in advancing our understanding of immune evasion by Orthopoxviruses and uncovering the elements of an effective immune response against these pathogens. This, in turn, could provide information that would be influential in guiding the development, testing, and implementation of other anti-Orthopoxvirus countermeasures. IFN- $\beta$ should also be considered for the treatment of adverse events associated with the smallpox vaccine, particularly for those conditions where vaccinia immunoglobulin is not recommended or is believed to be of limited utility. In conclusion, IFN- $\beta$ should be further developed for prophylactic and/or therapeutic use against MPXV, as well as investigated for efficacy against other highly pathogenic Orthopoxviruses including VARV.

\section{Methods}

Cells, viruses, and interferons

VA-9, VN36, and VA(R645) cell lines [53,54] were generously provided by Dr. Otto Haller (University of Freiburg, Germany). Monolayers of HeLa cells (ATCC, Manassas,

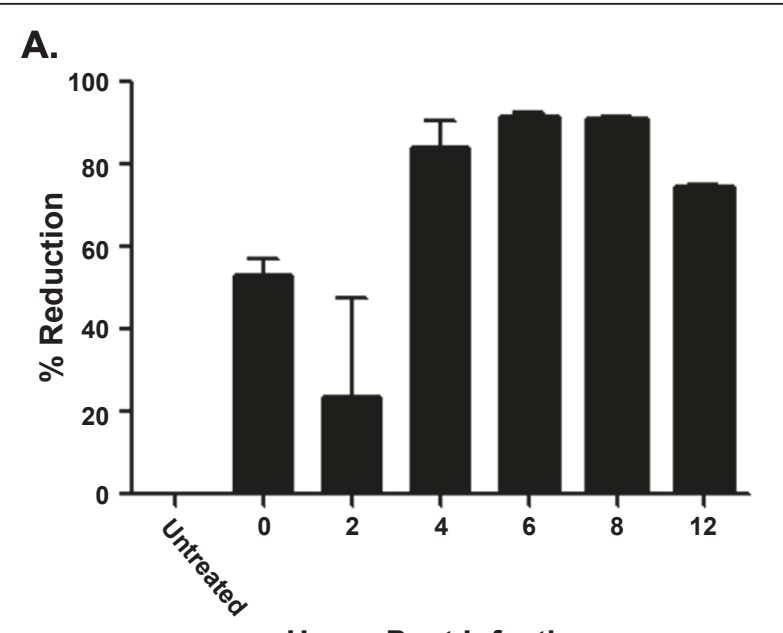

Hours Post Infection

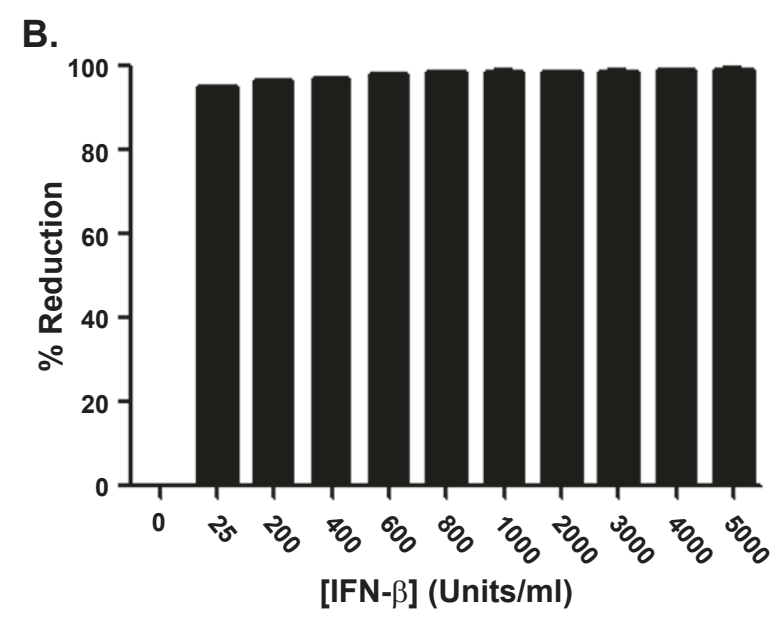

Figure 9 (a) Post-treatment assay. HeLa cells infected with MPXVZaire at an $\mathrm{MOI}=5$ in the presence or absence of $2000 \mathrm{U} / \mathrm{ml}$ of IFN- $\beta$ were treated with $2000 \mathrm{U} / \mathrm{ml}$ of IFN- $\beta$ at the indicated times after infection. The cells were harvested $24 \mathrm{~h}$ p.i. and lysates were titered by plaque assay. (b) Infection of fibroblast with MPXV. Normal human dermal fibroblasts were pre-treated for $24 \mathrm{~h}$ with $2000 \mathrm{U} / \mathrm{ml}$ of IFN- $\beta$. After pre-treatment, the cells were infected with MPXV-Zaire $(\mathrm{MOI}=5)$ in the presence or absence of $2000 \mathrm{U} / \mathrm{ml}$ of IFN- $\beta$. The cells were harvested $24 \mathrm{~h}$ p.i., and the amount of virus present in the lysates was titered by plaque assay.

VA) and normal human dermal fibroblasts (Lonza, Walkersville, MD) were maintained in Dulbecco's Modification of Eagle's Medium (Cellgro, Manassas, VA) containing $10 \%$ heat-inactivated fetal bovine serum, $1 \mathrm{X}$ glutamine, and 1X penicillin/streptomycin. Monolayers of Vero-E6, MA-104, VA-9, VN36, and VA(R645) cells were maintained in Minimum Essential Medium (Cellgro, Manassas, VA) containing 10\% heat-inactivated fetal bovine serum, $1 \mathrm{X}$ glutamine, and $1 \mathrm{X}$ penicillin/streptomycin. Cell counts were obtained before plating to assure that equal numbers of cells were used for all infections. All infections were performed in medium containing 
2.5\% heat-inactivated fetal bovine serum, $1 \mathrm{X}$ glutamine, and $1 \mathrm{X}$ penicillin/streptomycin. MPXV-Zaire-1971-005 was previously described $[67,68]$. Human IFN- $\beta$ 1a was obtained from PBL InterferonSource (Piscataway, NJ). As described on the data sheet from the manufacturer, this product was generated from cDNA isolated from human fibroblast mRNA expressed in CHO cells; it is not PEGylated. Upon arrival, the IFN was distributed to aliquots to minimize freeze-thawing, and stored at $-80^{\circ} \mathrm{C}$ as recommended by PBL Interferon Source to maintain activity.

\section{MPXV-GFP-tdTR generation and characterization}

MPXV-GFP-tdTR, which expresses GFP from the early viral synthetic $\mathrm{E} / \mathrm{L}$ promoter and tandem dimer Tomato Red (TR) from the late viral promoter 11, was generated as follows. An expression plasmid containing both fluorescent inserts was obtained from Dr. Grant McFadden (University of Florida). Confluent monolayers of Vero-E6 cells infected with MPXV-Zaire (MOI = 1) were transfected with $2 \mu \mathrm{g}$ of plasmid DNA in the presence of Lipofectamine 2000 (Invitrogen, Carlsbad, CA) according to the manufacturer's instructions. Cells were harvested $24 \mathrm{~h}$ p.i. and lysed by freeze-thawing, and the lysate was used to infect Vero-E6 cells. Plaques that fluoresced both green and red were purified a total of 4 times on Vero-E6 cells, and then amplified to high titer in MA-104 cells. The resulting purified recombinant virus, MPXV-GFP-tdTR, contained both fluorescent tags inserted into the intergenic region between J4R and J5L. Sequencing of this region confirmed proper insertion of tdTR and GFP. A plaque assay and high MOI $(\mathrm{MOI}=5)$ growth curve were performed as described previously [69] on confluent monolayers of Vero-E6 cells.

To confirm proper expression of GFP and tdTR, VeroE6 cells were infected with MPXV-GFP-tdTR $(\mathrm{MOI}=5)$ in the presence or absence of $50 \mu \mathrm{g} / \mathrm{ml}$ of Ara-C. After a $1 \mathrm{~h}$ incubation, the inoculum was removed, the cells washed, and fresh medium with and without $50 \mu \mathrm{g} / \mathrm{ml}$ of Ara-C was added. Images were acquired $48 \mathrm{~h}$ p.i. using a Nikon Eclipse te2000-s fluorescence microscope equipped with a SPOT RT Monochrome camera and overlaid using Adobe PhotoShop software.

\section{IFN- $\beta$ titration assay}

Monolayers of HeLa cells $\left(1 \times 10^{6}\right.$ cells/well $)$ or normal human dermal fibroblasts $\left(3 \times 10^{5}\right.$ cells/well $)$ were either left untreated or were pretreated with $0,200,400,600$, $800,1000,2000,3000,4000$, or $5000 \mathrm{U} / \mathrm{ml}$ of human IFN$\beta$ 1a (PBL InterferonSource, Piscataway, NJ). The cells were infected $24 \mathrm{~h}$ later with MPXV-Zaire at an MOI of 5 in the presence or absence of IFN- $\beta$. After $1 \mathrm{~h}$, the inoculum was removed, the cells washed, and fresh media with or without IFN- $\beta$ was added. The cells were harvested $24 \mathrm{~h}$ p.i., lysed by 3 cycles of freeze-thawing/sonication, and virus titers determined by plaque assay as described above.

To assess the therapeutic limit of IFN- $\beta$, cells were treated with $2000 \mathrm{U} / \mathrm{ml}$ of IFN- $\beta$ either $0,2,4,6$, 8 , or $12 \mathrm{~h}$ p.i. and infections and viral titers were performed as described above.

\section{Growth curves}

High MOI $(\mathrm{MOI}=5)$ and low MOI $(\mathrm{MOI}=0.01)$ growth curves were performed in duplicate as described previously [69]. Briefly, HeLa cells were either left untreated or were pre-treated with $2000 \mathrm{U} / \mathrm{ml}$ of IFN- $\beta$. The cells were infected $24 \mathrm{~h}$ later with MPXV-Zaire in the presence or absence of $2000 \mathrm{U} / \mathrm{ml}$ of IFN- $\beta$. For the $0 \mathrm{~h}$ time point, the inoculum was immediately removed, the cells were washed, $1 \mathrm{ml}$ of fresh medium was added to the cells, and the cells and medium were immediately harvested. For all other time points, the inoculum was removed $1 \mathrm{~h}$ p.i., the cells were washed, and $1 \mathrm{ml}$ of fresh medium with or without $2000 \mathrm{U} / \mathrm{ml}$ of IFN- $\beta$ was added. Fresh IFN- $\beta$ was added to the medium every $24 \mathrm{~h}$ p.i.. Cells and medium were harvested separately at $0,4,12,24$, and $48 \mathrm{~h}$ p.i. for the high MOI growth curve, and at $0,24,48,72,96$, and 120 h p.i. for the low MOI growth curve. Cells were lysed by three cycles of freeze-thawing/sonication (medium harvests were not freeze-thawed to maintain the integrity of viral membranes), and viral titers were determined by plaque assay as described above.

\section{Fluorescence and confocal microscopy}

HeLa cells grown on coverslips were either left untreated or were pre-treated $24 \mathrm{~h}$ before infection with $2000 \mathrm{U} / \mathrm{ml}$ of IFN- $\beta$. Cells were infected $24 \mathrm{~h}$ later with MPXV-GFPtdTR or MPXV-Zaire at a MOI of 5 in the presence or absence of IFN- $\beta$ and/or Ara-C $(50 \mu \mathrm{g} / \mathrm{ml})$. Cells were either imaged $24 \mathrm{~h}$ p.i. by using aNikon Eclipse te2000-s fluorescence microscope equipped with a SPOT ${ }^{\mathrm{TM}} \mathrm{RT}$ Monochrome camera (and overlaid using Adobe PhotoShop software) or were fixed in phosphate-buffered saline (PBS) containing 4\% paraformaldehyde in preparation for immunostaining. Fixed cells were permeabilized with PBS containing 0.1\% Triton X-100 (Sigma-Aldrich, St. Louis, $\mathrm{MO}$ ), quenched with PBS containing 0.1X glycine (SigmaAldrich, St. Louis, MO), and stained with an anti-MxA mAb (Sigma Aldrich, St. Louis, MO) followed by either Alexa Fluor 568-conjugated goat anti-rabbit IgG (Invitrogen, Carlsbad, CA) or Alexa Fluor 647-conjugated goat anti-rabbit IgG (Invitrogen, Carlsbad, CA). Additionally, cells infected with MPXV-Zaire were stained with an antiA33 monoclonal antibody (mAb) (generously provided by Dr. Jay Hooper, USAMRIID) followed by Alexa Fluor 488conjugated goat anti-mouse IgG (Invitrogen, Carlsbad, $\mathrm{CA}$ ). The coverslips were thoroughly washed and, following staining with Hoechst dye for $30 \mathrm{~min}$, were mounted 
onto slides using Fluoromount-G (SouthernBiotech, Birmingham, AL). Images were captured using a Leica TCS SP5 confocal microscope and overlaid using Leica Application Suite software. All relative fluorescence measurements were acquired using a SpectraMax Gemini EM Fluorescence Microplate Reader (Molecular Devices, Sunnyvale, CA).

\section{Infection of VA-9, VN36, and VA(R645) cell lines}

VA-9, VN36, and VA(R645) cells were infected with MPXV-Zaire or MPXV-GFP-tdTR at an MOI of 5. After absorption for $1 \mathrm{~h}$, the inoculum was removed, the cells were washed, and fresh medium was added. The cells infected with MPXV-Zaire were harvested $24 \mathrm{~h}$ p.i. and lysed by three cycles of freeze-thawing/sonication, and viral titers were determined by plaque assay as described above. Fluorescence microscopy was performed 24 h p.i. on cells infected with MPXV-GFP-tdTR using a Nikon Eclipse te2000-s fluorescence microscope equipped with a SPOT RT Monochrome camera and overlaid using Adobe PhotoShop software. Relative fluorescence measurements were acquired using a SpectraMax Gemini EM Fluorescence Microplate Reader (Molecular Devices, Sunnyvale, CA).

\section{Abbreviations}

IFN: Interferon; VARV: Variola virus; MPXV: Monkeypox virus; DRC: Democratic Republic of Congo; FDA: US Food and Drug Administration; H: Hours; PI:

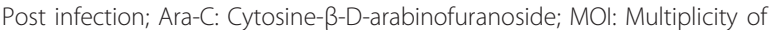
infection; GFP: Green fluorescent protein; tdTR: Tandem dimer Tomato Red; ASFV: African swine fever virus; U: Units; PBS: Phosphate-buffered saline.

\section{Acknowledgements}

We thank Dr. Otto Haller (University of Freiburg, Germany) for generously providing the VA-9 and VN36 cell lines, Dr. Jay Hooper (USAMRIID) for generously providing the anti-A33 monoclonal antibody, and Dr. Grant McFadden (University of Florida) for generously providing the GFP/TR expression plasmid. We thank Joe Shaw for assistance with manuscript preparation.

This work was funded by the Defense Threat Reduction Agency Project \# 195726. Opinions, interpretations, conclusions, and recommendations are those of the author and are not necessarily endorsed by the U.S. Army.

\section{Author details \\ ${ }^{1}$ Virology Division, United States Army Medical Research Institute of Infectious Diseases, 1425 Porter St. Fort Detrick, Frederick, MD 21702, USA. ${ }^{2}$ Toxicology Division, United States Army Medical Research Institute of Infectious Diseases, 1425 Porter St. Fort Detrick, Frederick, MD 21702, USA. ${ }^{3}$ Microbiology Department, Boston University School of Medicine and Microbiology, 72 E.Concord St R-Bd Boston, Boston, MA 02118, USA.}

\begin{abstract}
Authors' contributions
SCJ designed the study, conducted the majority of the assays presented, and drafted the manuscript. KLL performed the generation and characterization of MPXV-GFP-tdTR. JHC provided technical advice and helped to draft the manuscript. GR performed the imaging for the confocal microscopy assays. AG provided technical support and assisted with the generation of MPXV-GFP-tdTR. LEH provided technical support and helped to draft the manuscript. All authors read and approved the final manuscript.
\end{abstract}

Competing interests

The authors declare that they have no competing interests.
Received: 7 December 2011 Accepted: 6 January 2012

Published: 6 January 2012

\section{References}

1. Moss B: Poxviridae: the viruses and their replication. In Field's Virology. Volume 2.. 4 edition. Edited by: Knipe DM, Howley PM. Philadelphia: Lippincott-Raven; 2001:2849-2883.

2. Bahar MW, Graham SC, Chen RA, Cooray S, Smith GL, Stuart DI, Grimes JM: How vaccinia virus has evolved to subvert the host immune response. $J$ Struct Biol 2011, 175:127-134.

3. Gubser C, Hue S, Kellam P, Smith GL: Poxvirus genomes: a phylogenetic analysis. J Gen Virol 2004, 85:105-117.

4. Jackson SS, Ilyinskii P, Philippon V, Gritz L, Yafal AG, Zinnack K, Beaudry KR, Manson KH, Lifton MA, Kuroda MJ, et al: Role of genes that modulate host immune responses in the immunogenicity and pathogenicity of vaccinia virus. J Virol 2005, 79:6554-6559.

5. Altman LK: Health Workers Union Wary of Smallpox Vaccinations. The New York Times; 2002.

6. Henderson DA, Inglesby TV, Bartlett JG, Ascher MS, Eitzen E, Jahrling PB, Hauer J, Layton M, McDade J, Osterholm MT, et al: Smallpox as a biological weapon: medical and public health management. Working Group on Civilian Biodefense. JAMA 1999, 281:2127-2137.

7. Huhn GD, Bauer AM, Yorita K, Graham MB, Sejvar J, Likos A, Damon IK, Reynolds MG, Kuehnert MJ: Clinical characteristics of human monkeypox, and risk factors for severe disease. Clin Infect Dis 2005, 41:1742-1751.

8. Jezek Z, Szczeniowski M, Paluku KM, Mutombo M: Human monkeypox: clinical features of 282 patients. J Infect Dis 1987, 156:293-298.

9. Meyer $H$, Perrichot $M$, Stemmler $M$, Emmerich $P$, Schmitz $H$, Varaine $F$, Shungu R, Tshioko F, Formenty P: Outbreaks of disease suspected of being due to human monkeypox virus infection in the Democratic Republic of Congo in 2001. J Clin Microbiol 2002, 40:2919-2921.

10. Reynolds MG, Yorita KL, Kuehnert MJ, Davidson WB, Huhn GD, Holman RC, Damon IK: Clinical manifestations of human monkeypox influenced by route of infection. J Infect Dis 2006, 194:773-780.

11. Weaver JR, Isaacs SN: Monkeypox virus and insights into its immunomodulatory proteins. Immunol Rev 2008, 225:96-113.

12. Khodakevich $L$, Jezek $Z$, Kinzanzka K: Isolation of monkeypox virus from wild squirrel infected in nature. Lancet 1986, 1:98-99.

13. Khodakevich L, Szczeniowski M, Manbu ma D, Jezek Z, Marennikova S, Nakano J, Messinger D: The role of squirrels in sustaining monkeypox virus transmission. Trop Geogr Med 1987, 39:115-122.

14. Khodakevich L, Szczeniowski M, Nambu ma D, Jezek Z, Marennikova S, Nakano J, Meier F: Monkeypox virus in relation to the ecological features surrounding human settlements in Bumba zone, Zaire. Trop Geogr Med 1987, 39:56-63.

15. Hutin YJ, Williams RJ, Malfait P, Pebody R, Loparev VN, Ropp SL, Rodriguez M, Knight JC, Tshioko FK, Khan AS, et al: Outbreak of human monkeypox, Democratic Republic of Congo, 1996-1997. Emerg Infect Dis 2001, 7:434-438.

16. Jezek Z, Grab B, Paluku KM, Szczeniowski MV: Human monkeypox: disease pattern, incidence and attack rates in a rural area of northern Zaire. Trop Geogr Med 1988, 40:73-83.

17. Jezek Z, Grab B, Szczeniowski M, Paluku KM, Mutombo M: Clinicoepidemiological features of monkeypox patients with an animal or human source of infection. Bull World Health Organ 1988, 66:459-464.

18. Rimoin AW, Mulembakani PM, Johnston SC, Lloyd Smith JO, Kisalu NK, Kinkela TL, Blumberg S, Thomassen HA, Pike BL, Fair JN, et al: Major increase in human monkeypox incidence 30 years after smallpox vaccination campaigns cease in the Democratic Republic of Congo. Proc Natl Acad Sci USA 2010, 107:16262-16267.

19. Chen N, Li G, Liszewski MK, Atkinson JP, Jahrling PB, Feng Z, Schriewer J, Buck C, Wang C, Lefkowitz EJ, et al: Virulence differences between monkeypox virus isolates from West Africa and the Congo basin. Virology 2005, 340:46-63.

20. Ladnyj ID, Ziegler P, Kima E: A human infection caused by monkeypox virus in Basankusu Territory, Democratic Republic of the Congo. Bull World Health Organ 1972, 46:593-597.

21. Reed KD, Melski JW, Graham MB, Regnery RL, Sotir MJ, Wegner MV Kazmierczak JJ, Stratman EJ, Li Y, Fairley JA, et al: The detection of monkeypox in humans in the Western Hemisphere. N Engl J Med 2004, 350:342-350 
22. Learned LA, Reynolds MG, Wassa DW, Li Y, Olson VA, Karem K, Stempora LL, Braden $\mathrm{ZH}$, Kline R, Likos A, et al: Extended interhuman transmission of monkeypox in a hospital community in the Republic of the Congo, 2003. Am J Trop Med Hyg 2005, 73:428-434.

23. Biron CA: Role of early cytokines, including alpha and beta interferons (IFN-alpha/beta), in innate and adaptive immune responses to viral infections. Semin Immunol 1998, 10:383-390.

24. Randall RE, Goodbourn S: Interferons and viruses: an interplay between induction, signalling, antiviral responses and virus countermeasures. J Gen Virol 2008, 89:1-47.

25. Samuel CE: Antiviral actions of interferon. Interferon-regulated cellular proteins and their surprisingly selective antiviral activities. Virology 1991, 183:1-11.

26. Perdiguero B, Esteban M: The interferon system and vaccinia virus evasion mechanisms. J Interferon Cytokine Res 2009, 29:581-598.

27. Mohamed MR, Rahman MM, Lanchbury JS, Shattuck D, Neff C, Dufford M, van Buuren N, Fagan K, Barry M, Smith S, et al: Proteomic screening of variola virus reveals a unique NF-kappaB inhibitor that is highly conserved among pathogenic orthopoxviruses. Proc Natl Acad Sci USA 2009, 106:9045-9050.

28. Chang HW, Jacobs BL: Identification of a conserved motif that is necessary for binding of the vaccinia virus E3L gene products to double-stranded RNA. Virology 1993, 194:537-547.

29. Chang HW, Watson JC, Jacobs BL: The E3L gene of vaccinia virus encodes an inhibitor of the interferon-induced, double-stranded RNA-dependent protein kinase. Proc Natl Acad Sci USA 1992, 89:4825-4829.

30. Kim YG, Muralinath M, Brandt T, Pearcy M, Hauns K, Lowenhaupt K, Jacobs BL, Rich A: A role for Z-DNA binding in vaccinia virus pathogenesis. Proc Natl Acad Sci USA 2003, 100:6974-6979.

31. Kim YG, Lowenhaupt K, Oh DB, Kim KK, Rich A: Evidence that vaccinia virulence factor E3L binds to Z-DNA in vivo: Implications for development of a therapy for poxvirus infection. Proc Natl Acad Sci USA 2004, 101:1514-1518.

32. Brandt TA, Jacobs BL: Both carboxy-and amino-terminal domains of the vaccinia virus interferon resistance gene, $E 3 \mathrm{~L}$, are required for pathogenesis in a mouse model. J Virol 2001, 75:850-856.

33. Carroll K, Elroy-Stein O, Moss B, Jagus R: Recombinant vaccinia virus K3L gene product prevents activation of double-stranded RNA-dependent, initiation factor 2 alpha-specific protein kinase. J Biol Chem 1993, 268:12837-12842.

34. Davies MV, Elroy-Stein O, Jagus R, Moss B, Kaufman RJ: The vaccinia virus $\mathrm{K} 3 \mathrm{~L}$ gene product potentiates translation by inhibiting double-strandedRNA-activated protein kinase and phosphorylation of the alpha subunit of eukaryotic initiation factor 2. J Virol 1992, 66:1943-1950.

35. Sharp TV, Witzel JE, Jagus R: Homologous regions of the alpha subunit of eukaryotic translational initiation factor 2 (elF2alpha) and the vaccinia virus $\mathrm{K} 3 \mathrm{~L}$ gene product interact with the same domain within the dsRNA-activated protein kinase (PKR). Eur J Biochem 1997, 250:85-91.

36. Langland JO, Jacobs BL: The role of the PKR-inhibitory genes, E3L and $\mathrm{K} 3 \mathrm{~L}$, in determining vaccinia virus host range. Virology 2002, 299:133-141.

37. Meng X, Jiang C, Arsenio J, Dick K, Cao J, Xiang Y: Vaccinia virus K1L and C7L inhibit antiviral activities induced by type I interferons. J Virol 2009, 83:10627-10636.

38. Oguiura N, Spehner D, Drillien R: Detection of a protein encoded by the vaccinia virus $C 7 L$ open reading frame and study of its effect on virus multiplication in different cell lines. J Gen Virol 1993, 74(Pt 7):1409-1413.

39. Perkus ME, Goebel SJ, Davis SW, Johnson GP, Limbach K, Norton EK, Paoletti E: Vaccinia virus host range genes. Virology 1990, 179:276-286.

40. Shisler JL, Jin XL: The vaccinia virus K1L gene product inhibits host NFkappaB activation by preventing IkappaBalpha degradation. J Virol 2004, 78:3553-3560.

41. Backes S, Sperling KM, Zwilling J, Gasteiger G, Ludwig H, Kremmer E, Schwantes A, Staib C, Sutter G: Viral host-range factor C7 or K1 is essential for modified vaccinia virus Ankara late gene expression in human and murine cells, irrespective of their capacity to inhibit protein kinase R-mediated phosphorylation of eukaryotic translation initiation factor 2alpha. J Gen Virol 2010, 91:470-482.

42. Fernandez de Marco Mdel M, Alejo A, Hudson P, Damon IK, Alcami A: The highly virulent variola and monkeypox viruses express secreted inhibitors of type I interferon. FASEB J 2010, 24:1479-1488.
43. Day SL, Ramshaw IA, Ramsay AJ, Ranasinghe C: Differential effects of the type I interferons alpha4, beta, and epsilon on antiviral activity and vaccine efficacy. J Immunol 2008, 180:7158-7166.

44. Weimar W, Stitz L, Billiau A, Cantell K, Schellekens H: Prevention of vaccinia lesions in Rhesus monkeys by human leucocyte and fibroblast interferon. J Gen Virol 1980, 48:25-30.

45. Haller O, Gao S, von der Malsburg A, Daumke O, Kochs G: Dynamin-like MxA GTPase: structural insights into oligomerization and implications for antiviral activity. J Biol Chem 2010, 285:28419-28424.

46. Haller O, Kochs G: Human MxA protein: an interferon-induced dynaminlike GTPase with broad antiviral activity. J Interferon Cytokine Res 2010, 31:79-87.

47. Haller O, Stertz S, Kochs G: The Mx GTPase family of interferon-induced antiviral proteins. Microbes Infect 2007, 9:1636-1643.

48. Haller $\mathrm{O}$, Weber $\mathrm{F}$ : The interferon response circuit in antiviral host defense. Verh K Acad Geneeskd Belg 2009, 71:73-86.

49. Netherton $\mathrm{CL}$, Simpson J, Haller O, Wileman TE, Takamatsu HH, Monaghan P, Taylor G: Inhibition of a large double-stranded DNA virus by MxA protein. J Virol 2009, 83:2310-2320.

50. Pavlovic J, Zurcher T, Haller O, Staeheli P: Resistance to influenza virus and vesicular stomatitis virus conferred by expression of human MxA protein. J Virol 1990, 64:3370-3375.

51. Staeheli P, Pravtcheva D, Lundin LG, Acklin M, Ruddle F, Lindenmann J, Haller O: Interferon-regulated influenza virus resistance gene $\mathrm{Mx}$ is localized on mouse chromosome 16. J Virol 1986, 58:967-969.

52. Stertz S, Reichelt M, Krijnse-Locker J, Mackenzie J, Simpson JC, Haller O, Kochs G: Interferon-induced, antiviral human MxA protein localizes to a distinct subcompartment of the smooth endoplasmic reticulum. J Interferon Cytokine Res 2006, 26:650-660.

53. Frese M, Kochs G, Meier-Dieter U, Siebler J, Haller O: Human MxA protein inhibits tick-borne Thogoto virus but not Dhori virus. J Virol 1995, 69:3904-3909.

54. Zurcher T, Pavlovic J, Staeheli P: Mechanism of human MxA protein action: variants with changed antiviral properties. EMBO J 1992, 11:1657-1661.

55. Huggins J, Goff A, Hensley L, Mucker E, Shamblin J, Wlazlowski C, Johnson W, Chapman J, Larsen T, Twenhafel N, et al: Nonhuman primates are protected from smallpox virus or monkeypox virus challenges by the antiviral drug ST-246. Antimicrob Agents Chemother 2009, 53:2620-2625.

56. Kennedy RB, Ovsyannikova I, Poland GA: Smallpox vaccines for biodefense. Vaccine 2009, 27(Suppl 4):D73-79.

57. Wiser I, Balicer RD, Cohen D: An update on smallpox vaccine candidates and their role in bioterrorism related vaccination strategies. Vaccine 2007 25:976-984.

58. Everett WW, Coffin SE, Zaoutis T, Halpern SD, Strom BL: Smallpox vaccination: a national survey of emergency health care providers. Acad Emerg Med 2003, 10:606-611.

59. McNeil D: When parents say no to child vaccinations. The New York Times; 2002

60. Dropulic LK, Cohen J: Update on new antivirals under development for the treatment of double-stranded DNA virus infections. Clin Pharmacol Ther 2010, 88:610-619.

61. Baker RO, Bray M, Huggins JW: Potential antiviral therapeutics for smallpox, monkeypox and other orthopoxvirus infections. Antiviral Res 2003, 57:13-23.

62. Smee DF, Bailey KW, Wong MH, Sidwell RW: Effects of cidofovir on the pathogenesis of a lethal vaccinia virus respiratory infection in mice. Antiviral Res 2001, 52:55-62.

63. Stittelaar KJ, Neyts J, Naesens L, van Amerongen G, van Lavieren RF, Holy A De Clercq E, Niesters HG, Fries E, Maas C, et al: Antiviral treatment is more effective than smallpox vaccination upon lethal monkeypox virus infection. Nature 2006, 439:745-748.

64. Jahrling PB, Fritz EA, Hensley LE: Countermeasures to the bioterrorist threat of smallpox. Curr Mol Med 2005, 5:817-826.

65. Reeves PM, Bommarius B, Lebeis S, McNulty S, Christensen J, Swimm A, Chahroudi A, Chavan R, Feinberg MB, Veach D, et al: Disabling poxvirus pathogenesis by inhibition of Abl-family tyrosine kinases. Nat Med 2005 11:731-739.

66. Bolken TC, Hruby DE: Tecovirimat for smallpox infections. Drugs Today (Barc) 2010, 46:109-117. 
67. Goff AJ, Chapman J, Foster C, Wlazlowski C, Shamblin J, Lin K, Kreiselmeier N, Mucker E, Paragas J, Lawler J, Hensley L: A novel respiratory model of infection with monkeypox virus in cynomolgus macaques. $J$ Virol 2011, 85:4898-4909.

68. Jordan R, Goff A, Frimm A, Corrado ML, Hensley LE, Byrd CM, Mucker E, Shamblin J, Bolken TC, Wlazlowski C, et al: ST-246 antiviral efficacy in a nonhuman primate monkeypox model: determination of the minimal effective dose and human dose justification. Antimicrob Agents Chemother 2009, 53:1817-1822.

69. Ward BM, Moss B: Visualization of intracellular movement of vaccinia virus virions containing a green fluorescent protein-B5R membrane protein chimera. J Virol 2001, 75:4802-4813.

doi:10.1186/1743-422X-9-5

Cite this article as: Johnston et al:: In vitro inhibition of monkeypox virus production and spread by Interferon- $\beta$. Virology Journal 2012 9:5.

\section{Submit your next manuscript to BioMed Central} and take full advantage of:

- Convenient online submission

- Thorough peer review

- No space constraints or color figure charges

- Immediate publication on acceptance

- Inclusion in PubMed, CAS, Scopus and Google Scholar

- Research which is freely available for redistribution

Submit your manuscript at www.biomedcentral.com/submit 